\title{
Specific Heat Capacity of Wood
}

\section{Specifični toplinski kapacitet drva}

\author{
Review paper $\bullet$ Pregledni rad \\ Received-prispjelo: 16. 5. 2013. \\ Accepted-prihvaćeno: 9. 4. 2014. \\ UDK: $630 * 812.145$ \\ doi:10.5552/drind.2014.1333
}

\begin{abstract}
Specific heat capacity is defined as the amount of heat that a kilogram of a given substance is required to absorb in order to increase its temperature by one degree. The temperature of a given substance can change either at constant pressure or at constant volume, so we differentiate between specific heat capacity at constant pressure $\left(c_{p}\right)$ and specific heat capacity at constant volume $\left(c_{v}\right)$. When doing research into the heat properties of wood, the quantity that most frequently remains constant is pressure, thus restricting our study on specific heat capacity to $c_{p}$. This paper provides an overview of the research that has so far been carried out into the specific heat capacity of wood depending on the temperature and moisture content. An analytical and graphical comparison has been performed of the results published in the Wood Industry Manual (1967) (DIP), Wood Handbook (1999) (WH) and work published by Deliiski (2012) (DEL).
\end{abstract}

Key words: specific heat capacity, wood, moisture content, temperature

SAŽETAK • Specifični toplinski kapacitet definiramo kao količinu topline koju kilogram neke tvari treba primiti da bi povećao svoju temperaturu za jedan stupanj. Temperatura neke tvari može se mijenjati uz konstantan tlak ili konstantan volumen, pa razlikujemo specifični toplinski kapacitet pri konstantnom tlaku (c) i specifični toplinski kapacitet pri konstantnom volumenu $\left(c_{v}\right)$. Pri ispitivanju toplinskih svojstava drva najčešće je tlak veličina koja ostaje konstantna, zbog čega se naša razmatranja specifičnoga toplinskog kapaciteta ograničavaju na $c_{p}$. U radu su prikazani rezultati dosadašnjih istraživanja $c_{p}$ drva u ovisnosti o temperaturi i sadržaju vode. Obavljena je analitička i grafička usporedba rezultata objavljenih u Drvnoindustrijskom priručniku (1967.) (DIP), Wood Handbooku (1999.) (WH) i radu Deliiskog (2012.) (DEL).

Ključne riječi: specifični toplinski kapacitet, drvo, sadržaj vode, temperatura

\section{INTRODUCTION}

\section{UVOD}

The thermal properties of wood are essential physical properties, especially in the processes of drying, producing heat energy by combustion and other processes, which include the transfer of heat through wood. The thermal properties of wood are as follows: specific heat capacity $(c)$, coefficient of thermal conductivity $(k)$ and thermal diffusivity $(\alpha)$. These three properties of wood are interconnected by the expression:

$$
\alpha=\frac{k}{c \cdot \rho}
$$

where:

$\alpha$ - thermal diffusivity, $\mathrm{m}^{2} \cdot \mathrm{s}^{-1}$,

$k$ - coefficient of thermal conductivity, $\mathrm{W} / \mathrm{m} \cdot \mathrm{K}$,

$c$ - specific heat capacity, $\mathrm{J} / \mathrm{kg} \cdot{ }^{\circ} \mathrm{C}$,

$\rho$ - density, $\mathrm{kg} \cdot \mathrm{m}^{-3}$.

Wood, being a porous biomaterial, contains small holes that greatly influence the mechanism of heat transfer, and therefore also the specific heat capacity. Generally speaking, wood is a porous system composed of gas (air), liquid (water) and solid matter (wood). Water can be bound or free, and appears in a solid or liquid state (Chudinov, 1968; Twardowski et al., 2006). The maximum amount of bound water in

\footnotetext{
${ }^{1}$ Authors are assistant, assistant professor and professor at the Faculty of Forestry, University of Zagreb, Croatia.

${ }^{1}$ Autori su redom asistent, docent i profesor Šumarskog fakulteta Sveučilišta u Zagrebu.
} 
wood corresponds to its maximum hygroscopy, i.e. the moisture that the wood absorbs when the relative humidity of air equals $100 \%$. Maximum hygroscopy is called the fiber saturation point $\left(u_{\mathrm{fsp}}\right)$. The fiber saturation point depends on the type and density of wood.

In view of the structure of wood, it is considered that the specific heat capacity of wood $\left(c_{\mathrm{pw}}\right)$ is a sum of the specific heat capacity of a dry wood substance $\left(c_{\mathrm{p} 0}\right)$, the specific heat capacity of free water $\left(c_{\mathrm{pfw}}\right)$ and the specific heat capacity of bound water $\left(c_{\mathrm{pbw}}\right)$ (Deliiski, 2012).

$$
c_{\mathrm{pw}}=c_{\mathrm{p} 0}+c_{\mathrm{pfw}}+c_{\mathrm{pbw}}
$$

where:

$c_{\text {pw }}$ - specific heat capacity of wood, $\mathrm{J} / \mathrm{kg} \cdot{ }^{\circ} \mathrm{C}$,

$c_{\mathrm{p} 0}$ - specific heat capacity of wood of dry wood

substance, $\mathrm{J} / \mathrm{kg} \cdot{ }^{\circ} \mathrm{C}$,

$c_{\text {pfw }}$ - specific heat capacity of free water, $\mathrm{J} / \mathrm{kg} \cdot{ }^{\circ} \mathrm{C}$,

$c_{\mathrm{pbw}}$ - specific heat capacity of bound water, $\mathrm{J} / \mathrm{kg} \cdot{ }^{\circ} \mathrm{C}$.

If the volume of water is below the fiber saturation point, all of the water is bound, thus reducing the aforementioned expression to:

$$
c_{\mathrm{pw}}=c_{\mathrm{p} 0}+c_{\mathrm{pbw}}
$$

The specific heat capacity of free and bound water depends on the state of matter. Free and bound water change their state of matter at different temperatures. Free water in wood changes its state of matter in a temperature range of $-2{ }^{\circ} \mathrm{C}$ to $-0.1^{\circ} \mathrm{C}$, depending on the concentration of dissolved sugar in water (Kubler et al., 1964; Chudinov, 1968), whereas bound water undergoes only a partial phase change in a wide temperature range at temperatures lower than $-2{ }^{\circ} \mathrm{C}$.

\section{SPECIFIC HEAT CAPACITY OF DRY WOOD SUBSTANCE}

\section{SPECIFIČNI TOPLINSKI KAPACITET SUHE} DRVNE TVARI

Over the course of the twentieth century, a lot of researchers dealt with the issue of the specific heat capacity of dry wood substance $\left(c_{\mathrm{p} 0}\right)$. The main reference point in this area is Dunlop's paper from 1912. In this paper, the $c_{\mathrm{p} 0}$ is determined by means of a modified Bunsen ice calorimeter. For the purposes of the experiment, the samples were cylindrical in shape, between 3 $\mathrm{cm}$ and $9 \mathrm{~cm}$ in length, $1.7 \mathrm{~cm}$ in base diameter. Out of a total of 110 samples, using 20 different wood species, varying from 0.23 and 1.10 in specific weight, Dunlop determined the specific heat capacity of dry wood sub- stance in a temperature range of $0{ }^{\circ} \mathrm{C}$ to $112^{\circ} \mathrm{C}$. These results led to the conclusion that specific heat capacity does not depend on wood species or bulk density. The measurement results showed a linear dependence of specific heat capacity on the temperature ranging from $0{ }^{\circ} \mathrm{C}$ to $100{ }^{\circ} \mathrm{C}$, as demonstrated by equation (4). On the basis of the data obtained by measurement, the value of constant $A$ and $B$ in equation (4) was determined. In the temperature range of $100{ }^{\circ} \mathrm{C}$ to $112{ }^{\circ} \mathrm{C}$ no connection between $c_{\mathrm{p} 0}$ and temperature was established; on the basis of the data obtained by measurement, the average specific heat capacity for the given temperature interval was determined by means of equation (5) and it is $1.3688 \mathrm{~kJ} / \mathrm{kg} \cdot{ }^{\circ} \mathrm{C}$.

$$
\left\{c_{\mathrm{p}}\right\}_{\mathrm{J} / \mathrm{kg} \cdot{ }^{\circ} \mathrm{C}}=A+B \cdot\{t\}_{{ }^{\circ} \mathrm{C}}
$$

where:

$A$ - constant that represents specific heat capacity at $0{ }^{\circ} \mathrm{C}$, $B$ - constant that represents the slope of a line, $t$ - temperature.

$$
\bar{c}_{\mathrm{p}}=\frac{\int_{t_{0}}^{t_{1}} c_{\mathrm{p}}}{t_{1}-t_{0}}
$$

where: $\bar{c}_{\mathrm{p}}$ - mean specific heat capacity, $\mathrm{J} / \mathrm{kg} \cdot{ }^{\circ} \mathrm{C}$,

$c_{\mathrm{p}}$ - specific heat capacity, $\mathrm{J} / \mathrm{kg} \cdot{ }^{\circ} \mathrm{C}$,

$t_{0}$ - initial temperature, ${ }^{\circ} \mathrm{C}$,

$t_{1}$ - final temperature, ${ }^{\circ} \mathrm{C}$.

Dunlop (1912), Volbehr (1896) and Koch (1969) measured the $c_{\mathrm{p} 0}$ for several types of wood in a temperature range of $0{ }^{\circ} \mathrm{C}$ to $100{ }^{\circ} \mathrm{C}$, while Kanter (1957) measured the specific heat capacity in a temperature range of $-40{ }^{\circ} \mathrm{C}$ to $100{ }^{\circ} \mathrm{C}$. The data obtained by the aforesaid authors showed a linear dependence of $c_{\mathrm{p} 0}$ on temperature. On the basis of the data obtained by measurement, coefficients $A$ and $B$ (Table 1) in equation (4) were determined. Coefficient $A$ represents $c_{\mathrm{p} 0}$ at the temperature of $0{ }^{\circ} \mathrm{C}$, and coefficient $B$ determines the slope of the line. These results led to the conclusion that $c_{\mathrm{p} 0}$ does not depend on the wood species, density or specific weight.

Table 1 clearly shows that the data published by certain researchers (Dunlop, 1912; Volbehr, 1896; Koch, 1969) are only slightly different, while the data of the research done by Kanter (1957) coincides closely with the other authors in constant $B$, whereas the specific heat capacity at $0{ }^{\circ} \mathrm{C}$ is significantly different from the values obtained by the other authors. However, apart from Kanter (1957), none of the other au-

Table 1 Comparison of constants $A$ and $B$ in equation (4), average specific heat capacity of dry wood substance $\bar{c}_{\mathrm{p}_{01}}$ in a temperature range of $0{ }^{\circ} \mathrm{C}$ to $100{ }^{\circ} \mathrm{C}$ and average specific heat capacity of dry wood substance $\bar{c}_{\mathrm{p}_{02}}$ in a temperature range of $-40{ }^{\circ} \mathrm{C}$ to $100^{\circ} \mathrm{C}$ according to the research by Dunlop (1912), Volbehr (1896), Koch (1969) and Kanter (1957)

Tablica 1. Usporedba konstanti $A$ i $B$ u jednadžbi (4), srednji specifični toplinski kapacitet suhe drvne tvari $\bar{c}_{\mathrm{p}_{01}}$ u temperaturnom rasponu od 0 do $100{ }^{\circ} \mathrm{C}$ i srednji specifični toplinski kapacitet suhe drvne tvari $\bar{c}_{\mathrm{p}_{02}} \mathrm{u}$ temperaturnom rasponu od -40 do $100{ }^{\circ} \mathrm{C}$ prema istraživanjima Dunlopa (1912.), Volbehra (1896.), Kocha (1969.) i Kantera (1957.)

\begin{tabular}{|c|c|c|c|c|}
\hline Author / Autor & $A$ & $B$ & $\bar{c}_{\mathrm{p}_{01}}\left(0{ }^{\circ} \mathrm{C}-100{ }^{\circ} \mathrm{C}\right), \mathrm{kJ} / \mathrm{kg} \cdot{ }^{\circ} \mathrm{C}$ & $\bar{c}_{\mathrm{p}_{02}}\left(-40{ }^{\circ} \mathrm{C}-100{ }^{\circ} \mathrm{C}\right), \mathrm{kJ} / \mathrm{kg} \cdot{ }^{\circ} \mathrm{C}$ \\
\hline Dunlop & 1.1136 & 0.004856 & 1.3564 & 1.2592 \\
\hline Volbehr & 1.0841 & 0.005060 & 1.3371 & 1.2359 \\
\hline Koch & 1.1097 & 0.004202 & 1.3198 & 1.2357 \\
\hline Kanter & 1.5488 & 0.005023 & 1.7999 & 1.6994 \\
\hline
\end{tabular}


thors provides such high values of the specific heat capacity at the temperature of $0{ }^{\circ} \mathrm{C}$.

It should be noted that Wilkes and Wood (1949) determined the average specific heat capacity of 1.427 $\mathrm{kJ} / \mathrm{kg} \cdot{ }^{\circ} \mathrm{C}$ of a fiberboard, the density of which was $0.232 \mathrm{~g} / \mathrm{cm}^{3}$, in a temperature range of $27^{\circ} \mathrm{C}$ to $100^{\circ} \mathrm{C}$.

For the same temperature interval, the result of $1.421 \mathrm{~kJ} / \mathrm{kg} \cdot{ }^{\circ} \mathrm{C}$ is obtained by the Dunlop equation (1912), which differs slightly from Wilkes and Wood. Using the Kirsher method of measuring the specific heat capacity, Kühlman (1962) obtained values very similar to those obtained by Dunlop. Different sample preparations and use of different measuring devices provide an explanation for the subtle differences in the results.

Several authors (Brown et al., 1952; Emchenko, 1958; Tiemann, 1951) misquote Dunlop by stating that constant $A$ is $0.946 \mathrm{~kJ} / \mathrm{kg} \cdot{ }^{\circ} \mathrm{C}\left(0.226 \mathrm{kcal} / \mathrm{kg} \cdot{ }^{\circ} \mathrm{C}\right)$ instead of $1.1134 \mathrm{~kJ} / \mathrm{kg} \cdot{ }^{\circ} \mathrm{C}\left(0.266 \mathrm{kcal} / \mathrm{kg} \cdot{ }^{\circ} \mathrm{C}\right)$.

\subsection{Specific heat capacity of wood}

\subsection{Specifični toplinski kapacitet drva}

Volbehr (1896) determines the average specific heat capacity of wood fibers $\bar{c}_{\mathrm{pw}}$ in a temperature range of $0{ }^{\circ} \mathrm{C}$ to $100{ }^{\circ} \mathrm{C}$, with the wood moisture content $(u)$ varying between $0 \%$ and $30 \%$. In the said temperature range and moisture content, the $\bar{c}_{\mathrm{pw}}$ was higher than the $\bar{c}_{\mathrm{p} 0}$ of dry wood substance in the same temperature range. On the basis of the data obtained by measurement, he draws the conclusion that $\bar{c}_{\mathrm{pw}}$, apart from depending on a change in temperature, also depends on the volume of water. The mathematical dependence of $\overline{\mathrm{c}}_{\mathrm{pw}}$ on the temperature and volume of water is shown in expression (6).

$$
\begin{aligned}
\left\{\bar{c}_{\mathrm{pw}}\right\}_{\mathrm{kJ} / \mathrm{kg} \cdot{ }^{\circ} \mathrm{C}}= & 1.08+4.08 \cdot 10^{-3} \cdot\{u\}_{\%}+2.53 \cdot 10^{-3} \cdot\{t\}_{{ }^{\circ} \mathrm{C}}+ \\
& +6.28 \cdot 10^{-5} \cdot\{u\}_{\%} \cdot\{t\}_{{ }^{\circ} \mathrm{C}}
\end{aligned}
$$

where:

$\bar{c}_{\mathrm{pw}}$ - mean specific heat capacity of wood fiber, $\mathrm{kJ} / \mathrm{kg} \cdot{ }^{\circ} \mathrm{C}$, $u$ - moisture content, $\%$,

$t$ - temperature, ${ }^{\circ} \mathrm{C}$

Expression (6) served as a means to determine the $\bar{c}_{\mathrm{pw}}$ with the wood moisture content between $0 \%$ and $25 \%$ in a temperature range of $0{ }^{\circ} \mathrm{C}$ to $100{ }^{\circ} \mathrm{C}$. The obtained values can be seen in Figure (1).

Volbehr's research is tangible proof of the influence of the wood moisture content on the specific heat capacity of wood fibers.

Kanter (1957) determines the specific heat capacity of pine, oak and birch in a temperature range of - 40 ${ }^{\circ} \mathrm{C}$ to $100{ }^{\circ} \mathrm{C}$, with the moisture content varying between $0 \%$ and $130 \%$ (Figure 2). This data leads to the conclusion that the specific heat capacity of wood depends on the temperature and moisture content, while the variations between different wood species were very small.

The dependence of $c_{\mathrm{pw}}$ on temperature is linear in a range of moisture content from $5 \%$ to $30 \%$, but for temperatures below $0{ }^{\circ} \mathrm{C}$ this dependence is broken into two lines with a different slope coefficient. This change in slope coefficients occurs at the temperature at which change in the phase of bound water ends.

For wood moisture content higher than $30 \%$, the dependence of $c_{\mathrm{pw}}$ on temperature is also linear with a sudden rise at a temperature slightly lower than $0{ }^{\circ} \mathrm{C}$. This sudden rise is due to a change in the phase of free

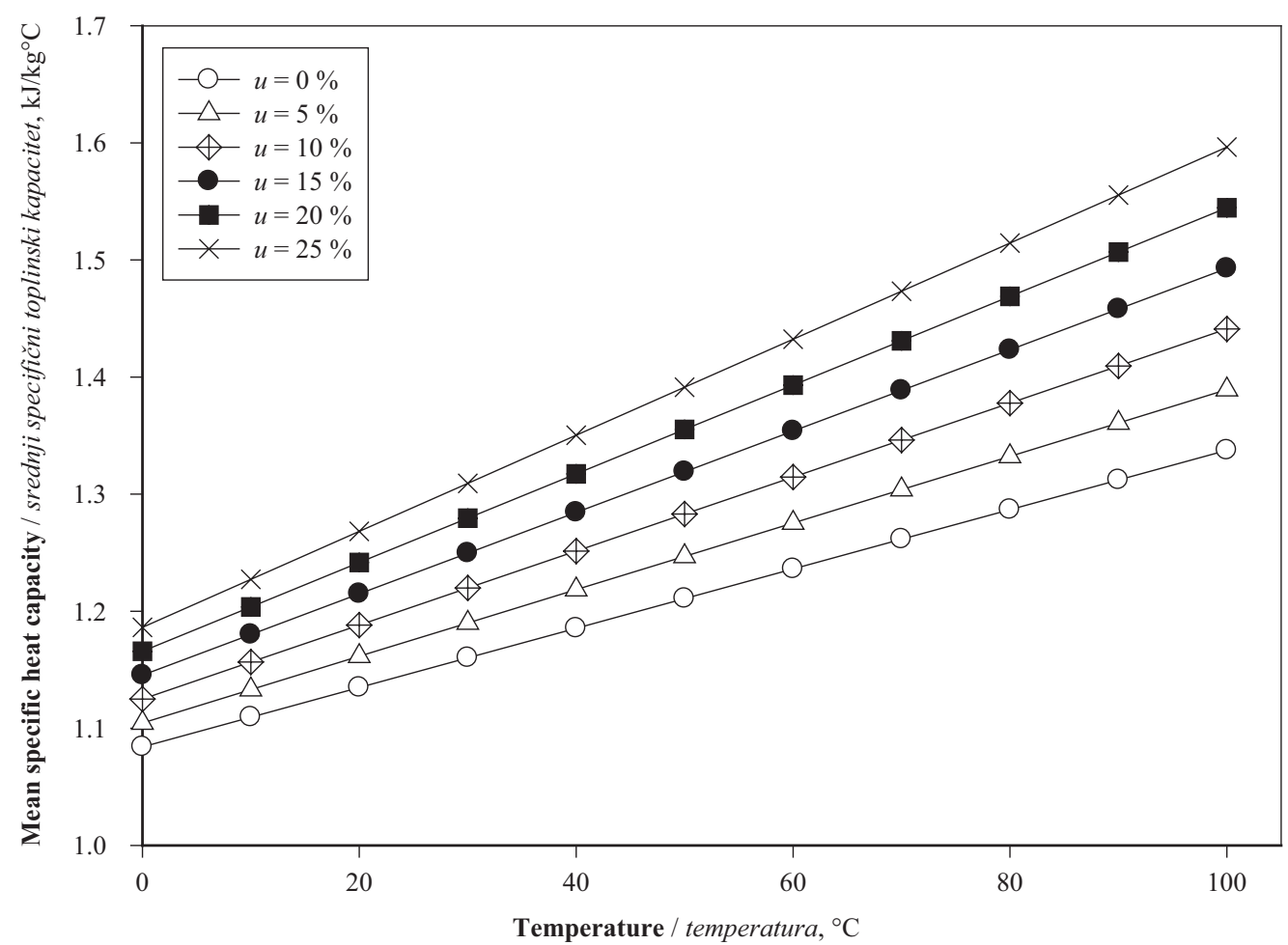

Figure 1 Dependence of specific heat capacity of wood fibers $\left(\bar{c}_{\mathrm{pw}}\right)$ on temperature with wood moisture content between $0 \%$ and $25 \%$

Slika 1. Ovisnost specifičnoga toplinskog kapaciteta drvnih vlakanaca $\left(\bar{c}_{\mathrm{pw}}\right)$ o temperaturi za sadržaj vode od 0 do $25 \%$ 


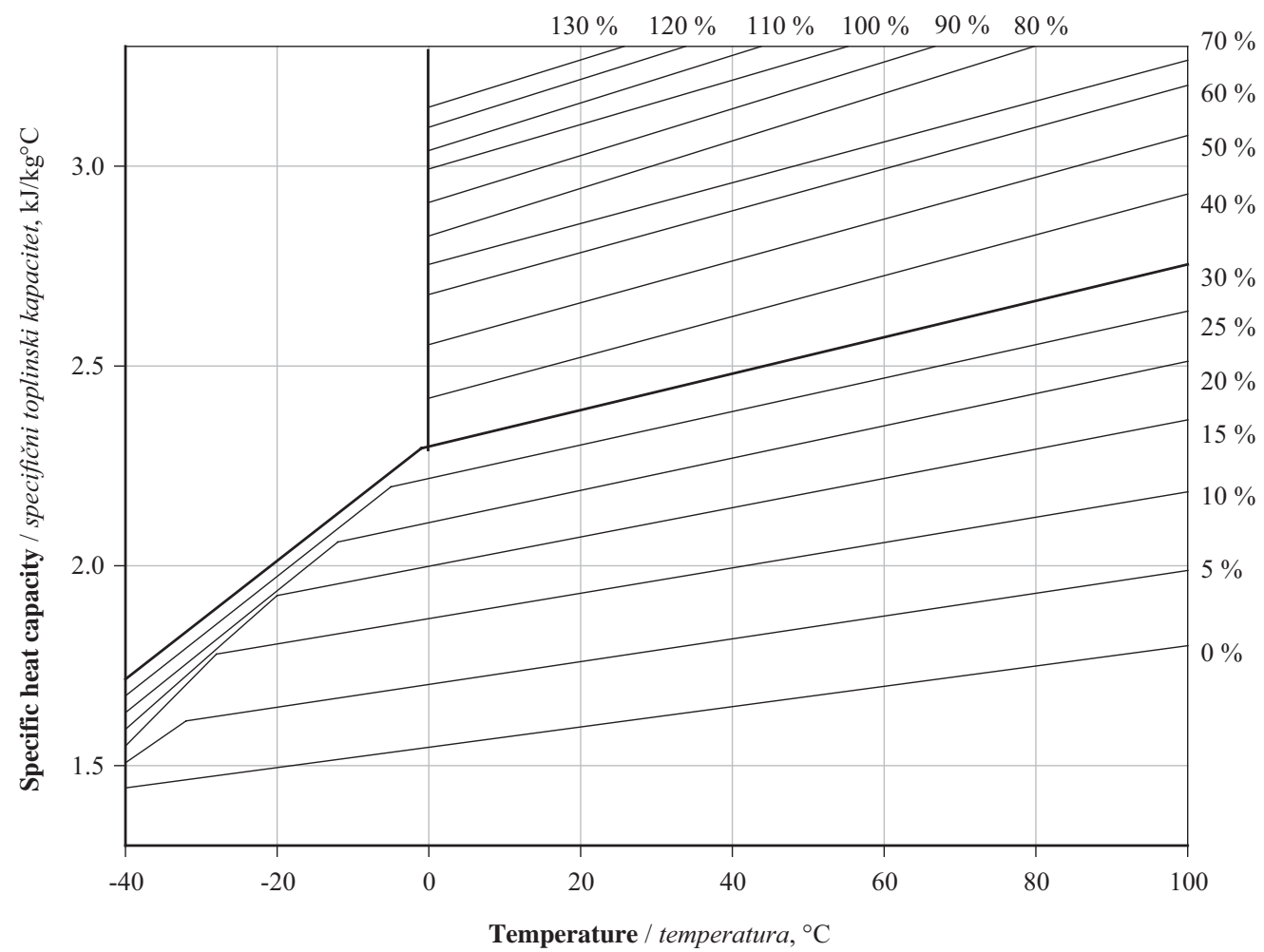

Figure 2 Dependence of specific heat capacity of wood on temperature (Kanter, 1957) and wood moisture content between $0 \%$ and $130 \%$

Slika 2. Ovisnost specifičnoga toplinskog kapaciteta drva o temperaturi (Kanter, 1957.) za sadržaj vode od 0 do $130 \%$

water. At this point, there is also the change in the slope coefficient of the line.

Kuhlman (1962) determines the specific heat capacity of spruce, oak and beech wood in a temperature range of $-60{ }^{\circ} \mathrm{C}$ to $80{ }^{\circ} \mathrm{C}$, with the moisture content below $30 \%$, by means of two different methods (the Esdorn - Kirsher method and the ice calorimeter method). Contrary to Kanter (1957), there were no significant changes in the specific heat capacity due to a change in the phase of bound water. The obtained values are considerably lower than those obtained by Kanter, but they coincide closely with the values obtained by the other authors at temperatures higher than $0{ }^{\circ} \mathrm{C}$. Table 2 shows the average deviations of the available results of the other authors from Kanter's results.

Most of the authors arrive at the conclusion that the specific heat capacity of wood depends on the temperature and moisture content, while variations between wood species are very small. The available literature provides only two papers that mention greater variations between wood species. Narayanamurti et al. (1958) measured the specific heat capacity of nine Indian wood species (probably at room temperature), and the results cover the interval of (1.29 to 1.73$) \mathrm{kJ} / \mathrm{kg} \cdot{ }^{\circ} \mathrm{C}$. Koch (1969) published the results on the specific heat capacity

Table 2 The average deviations of the results of the other authors from Kanter's results for temperatures lower and higher than $0{ }^{\circ} \mathrm{C}$ and moisture content below and above $30 \%$ (The USDA forest service general technical report FPL9, 1977)

Tablica 2. Srednja odstupanja rezultata ostalih autora od Kanterovih rezultata za temperature manje i veće od $0{ }^{\circ} \mathrm{C}$ te za sadržaj vode manji i veći od 30 \% (USDA forest service general technical report FPL9, 1977.)

\begin{tabular}{|l|c|c|c|c|}
\hline \multirow{2}{*}{ Author / Autor } & \multicolumn{3}{|c|}{ Mean deviation / Srednje odstupanje, \% } \\
\cline { 2 - 4 } & \multicolumn{2}{|c|}{$t<0{ }^{\circ} \mathrm{C}$} & $u \leq 30 \%$ & $u>30 \%$ \\
\cline { 2 - 4 } & $u \leq 30 \%$ & $u>30 \%$ & NA & NA \\
\hline Chudinov (1968) & +6 & +6 & NA & NA \\
\hline Chudinov, Stepanov (1971) & +14 & +21 & -19 & NA \\
\hline Dunlop (1912) & NA & NA & -15 & NA \\
\hline Emchenko (1958) & NA & NA & -13 & NA \\
\hline Hearmon, Burcham (1955) & NA & NA & - & - \\
\hline Kanter (1957) & - & - & -18 & NA \\
\hline Koch (1969) & NA & NA & +1 & +1 \\
\hline Komissarov (1969) & +1 & +1 & -17 & NA \\
\hline Kuhlmann (1962) & -20 & NA & -18 & NA \\
\hline McMillin (1969) & NA & NA & -28 & NA \\
\hline Volbehr (1896) & NA & NA & & \\
\hline
\end{tabular}


of earlywood and latewood, as well as of hardwoods and softwoods. The results also suggest the possibility of variations between different types of wood.

Theoretical research into the specific heat capacity of wood was also directed at establishing a model of heat diffusion in the wood. A model that provides a satisfactory description of the change in the specific heat capacity with the change in the temperature and moisture content is obtained by solving the FourierKirchhoff equation (Deliiski, 2012).

\section{DISCUSSION}

\section{RASPRAVA}

Due to the difference in results obtained by many authors, a comparison was drawn between the theoretical research conducted by Deliiski (2012) (DEL) and the research mentioned in the Wood Handbook (1999) (WH) and the Wood Technology Handbook (1967) (DIP). The temperature interval selected for the comparison was between $10^{\circ} \mathrm{C}$ and $100{ }^{\circ} \mathrm{C}$, and it results from a cross section of temperature intervals found in the literature. By means of equations from the studied literature, the specific heat capacity of wood was determined for a moisture content below the fiber saturation point (Figure 3) and for a moisture content above the fiber saturation point (Figure 4). It was assumed that the fiber saturation point corresponds to $25 \%$ moisture content. Figures 3 and 4 clear- ly show that the research confirmed a linear dependence of the specific heat capacity of wood on temperature in the given temperature interval. The linearity is only disturbed in the Deliiski equation, but the term disturbing the linearity is very small; it equals $\frac{0,02}{\{u\}_{\%}+100}$, the order of magnitude of which is $10^{-4}$. It should be noted that the results of the research mentioned in DIP cite the same equation of dependence of specific heat capacity on temperature, independent of the fiber saturation point. The equation of dependence of specific heat capacity on temperature in the research mentioned in the Wood Handbook is true in a temperature range of $7^{\circ} \mathrm{C}$ to $147^{\circ} \mathrm{C}$, but the equation contains a linear dependence of $c_{\mathrm{p} 0}$ on temperature, which, according to Dunlop's research, is linear in a temperature range of $0{ }^{\circ} \mathrm{C}$ to $100^{\circ} \mathrm{C}$.

By means of equation (5), the expression for the specific heat capacity was determined in a temperature range of $10^{\circ} \mathrm{C}$ to $100{ }^{\circ} \mathrm{C}$. The obtained average values are represented by equations (7), (8) and (9) for a moisture content below the fiber saturation point, and by equations (10), (11) and (12) for a moisture content above the fiber saturation point. Using the above equations, the average values of specific heat capacity were obtained for a moisture content between $0 \%$ and $20 \%$ (Figure 5) and for a moisture content between $80 \%$ and $100 \%$ (Figure 6). It is assumed that the fiber saturation point corresponds to $25 \%$ wood moisture content.

$$
\begin{aligned}
& \left\{\bar{c}_{\mathrm{pw}(\mathrm{WH})}\right\}_{\mathrm{kJkg} \cdot{ }^{\circ} \mathrm{C}}=\frac{0.1031+0.0419 \cdot\{u\}_{\%}}{1+0.01 \cdot\{u\}_{\%}}+\frac{1.268}{1+0.01 \cdot\{u\}_{\%}}-6.191 \cdot 10^{-2} \cdot\{u\}_{\%}-1.33 \cdot 10^{-4} \cdot\left\{u^{2}\right\}_{\%}+0.0774 \cdot\{u\}_{\%} \\
& \left\{\bar{c}_{\mathrm{pw}(\mathrm{DEL})}\right\}_{\mathrm{J} / \mathrm{kg} \cdot{ }^{\circ} \mathrm{C}}=\frac{2097 \cdot\{u\}_{\%}+82600}{\{u\}_{\%}+100}+\frac{9.92 \cdot\{u\}_{\%}+255}{\{u\}_{\%}+100} \cdot \frac{\left\{T_{1}\right\}_{\mathrm{K}}+\left\{T_{0}\right\}_{\mathrm{K}}}{2}+\frac{0.02}{\{u\}_{\%}+100} \cdot \frac{\left\{T_{1}^{3}\right\}_{\mathrm{K}}-\left\{T_{0}^{3}\right\}_{\mathrm{K}}}{3}
\end{aligned}
$$

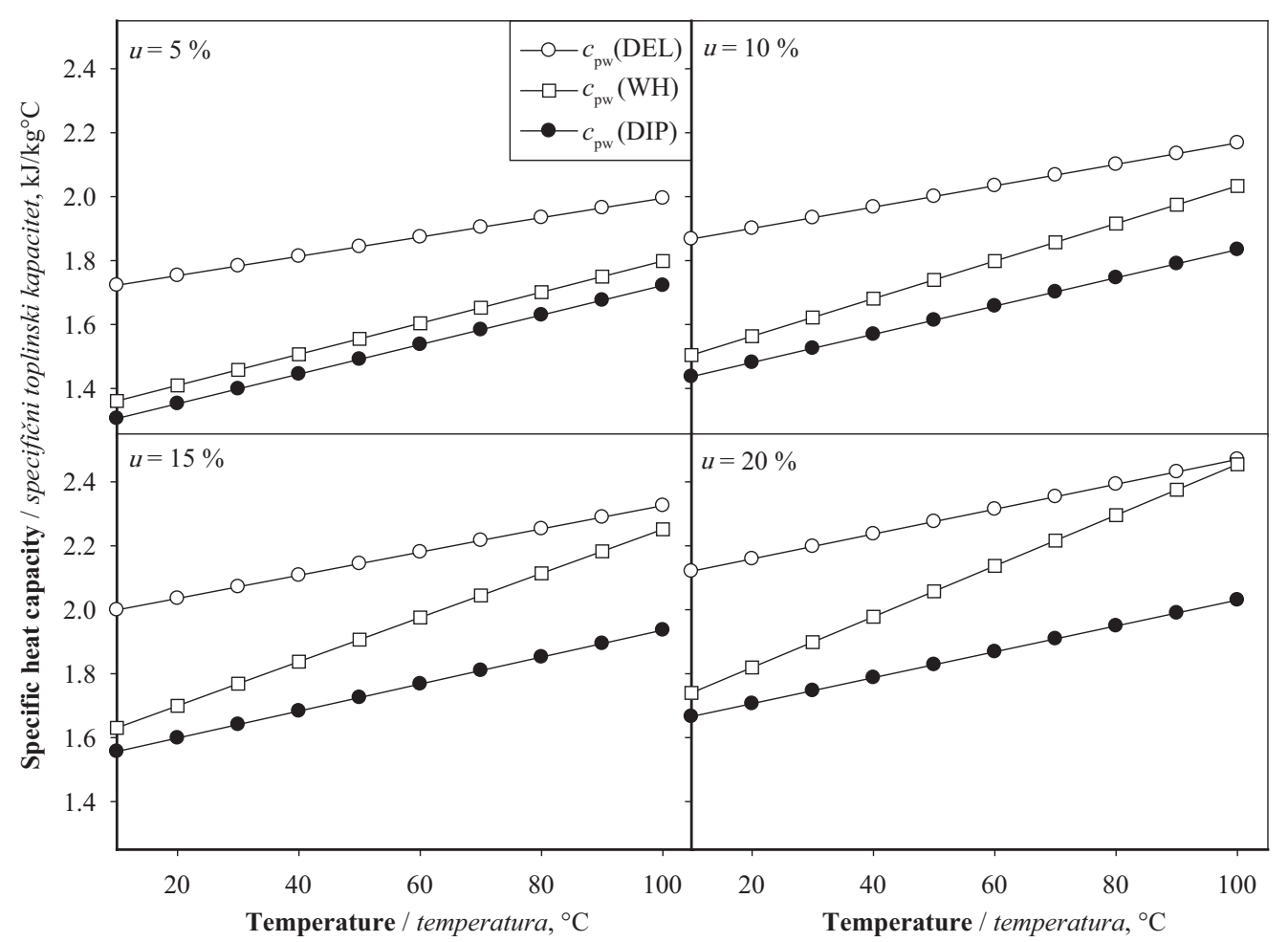

Figure 3 Dependence of specific heat capacity on temperature for a moisture content between $5 \%$ and $20 \%$, according to DEL, WH and DIP

Slika 3. Ovisnost specifičnoga toplinskog kapaciteta o temperaturi prema DEL-u, WH-u i DIP-u za sadržaj vode od 5 do $20 \%$ 


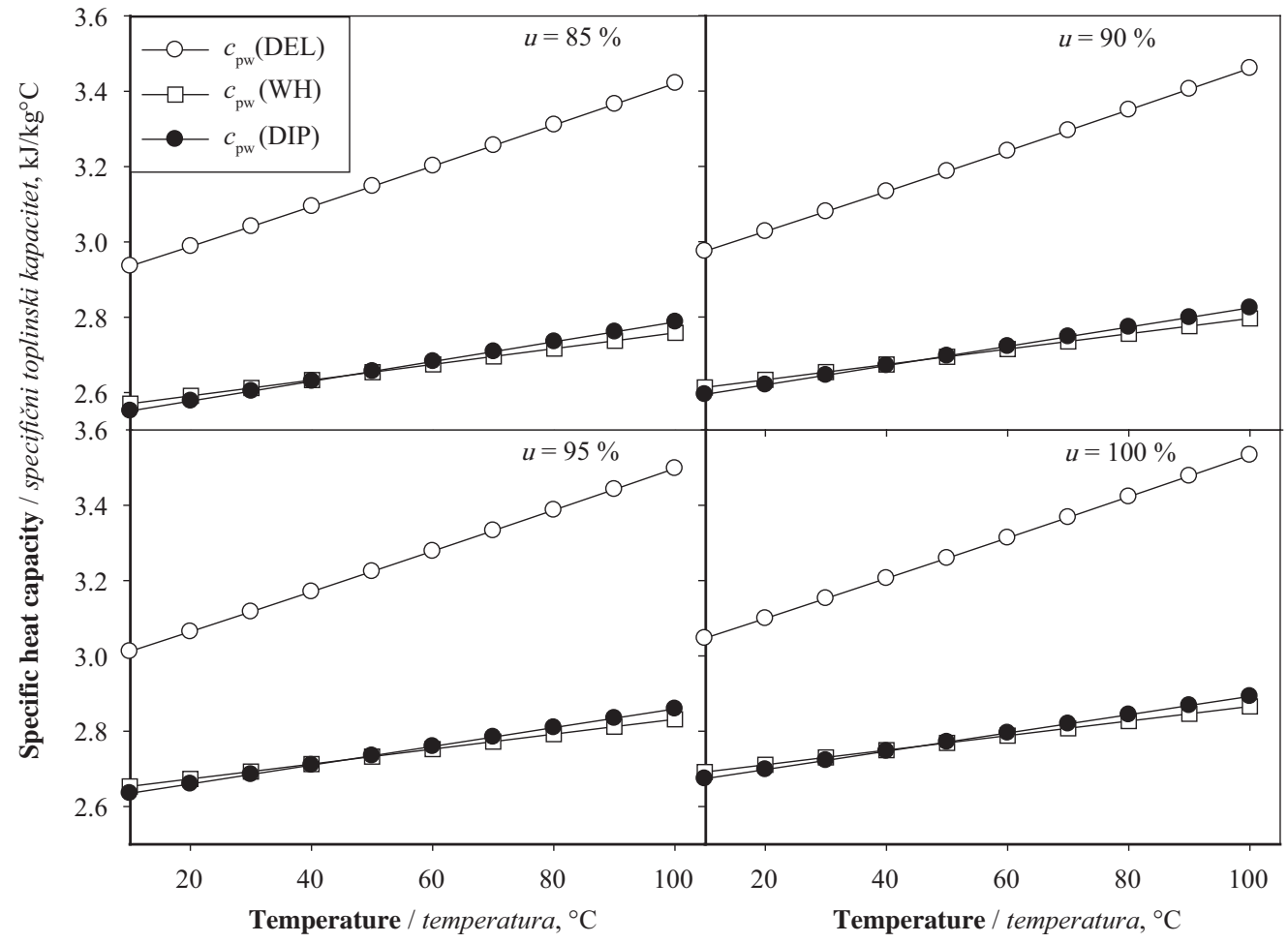

Figure 4 Dependence of specific heat capacity on temperature for a moisture content between $80 \%$ and $100 \%$, according to DEL, WH and DIP

Slika 4. Ovisnost specifičnoga toplinskog kapaciteta o temperaturi prema DEL-u, WH-u i DIP-u za sadržaj vode od 80 do $100 \%$

$\left\{\bar{c}_{\mathrm{pw}(\mathrm{DIP})}\right\}_{\mathrm{kJ} / \mathrm{kg} \cdot{ }^{\circ \mathrm{C}}}=\left(1-\frac{100}{100+\{u\}_{\%}}+\frac{26.6}{100+\{u\}_{\%}}+\frac{0.116}{100+\{u\}_{\%}} \cdot \frac{\left\{t_{1}\right\}_{{ }^{\circ} \mathrm{C}}+\left\{t_{0}\right\}_{{ }^{\circ} \mathrm{C}}}{2}\right) \cdot 4.186$

$\left\{\bar{c}_{\mathrm{pw}(\mathrm{WH})}\right\}_{\mathrm{kJ} / \mathrm{kg} \cdot{ }^{\circ \mathrm{C}}}=\frac{0.1031+0.0419 \cdot\{u\}_{\%}}{1+0.01 \cdot\{u\}_{\%}}+\frac{1.268}{1+0.01 \cdot\{u\}_{\%}}$

$\left\{\bar{c}_{\mathrm{pw}(\mathrm{DEL})}\right\}_{\mathrm{J} / \mathrm{kg} \cdot{ }^{\circ} \mathrm{C}}=\frac{2862 \cdot\{u\}_{\%}+55500}{\{u\}_{\%}+100}+\frac{5.49 \cdot\{u\}_{\%}+295}{\{u\}_{\%}+100} \cdot \frac{\left\{T_{1}\right\}_{\mathrm{K}}+\left\{T_{0}\right\}_{\mathrm{K}}}{2}+\frac{0.36}{\{u\}_{\%}+100} \cdot \frac{\left\{T_{1}^{3}\right\}_{\mathrm{K}}-\left\{T_{0}^{3}\right\}_{\mathrm{K}}}{3}$

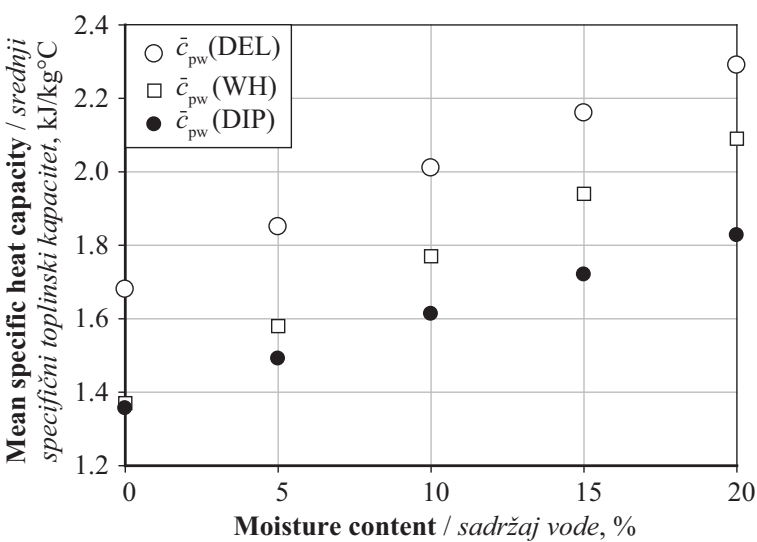

Figure 5 Dependence of the average specific heat capacity on moisture content for temperature ranging between $10^{\circ} \mathrm{C}$ and $100{ }^{\circ} \mathrm{C}\left(u<u_{\text {fsp }}\right)$

Slika 5. Ovisnost srednjeg specifičnoga toplinskog kapaciteta o sadržaju vlage za temperaturni interval od 10 do $100{ }^{\circ} \mathrm{C}$; sadržaj vode je manji od točke zasićenja vlakanaca

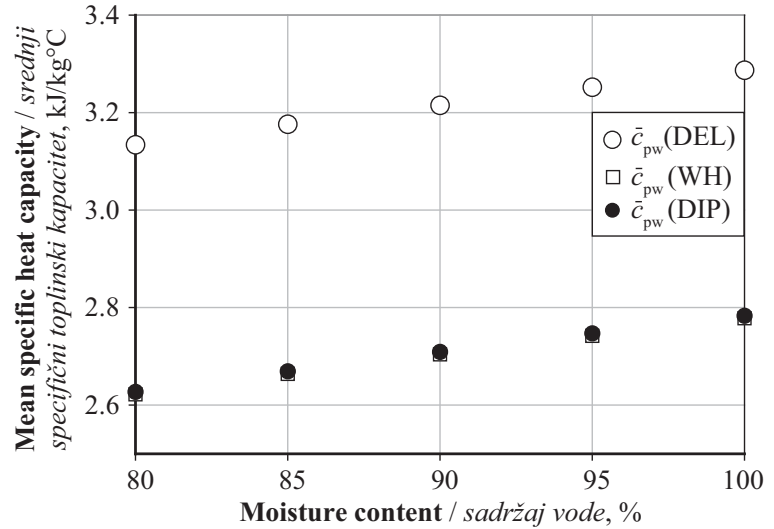

Figure 6 Dependence of the average specific heat capacity on wood moisture content for temperature ranging between $10^{\circ} \mathrm{C}$ and $100^{\circ} \mathrm{C}\left(u>u_{\text {fsp }}\right)$

Slika 6. Ovisnost srednjega specifičnog toplinskog kapaciteta o sadržaju vode za temperaturni interval od 10 do $100{ }^{\circ} \mathrm{C}$; sadržaj vode je veći od točke zasićenja vlakanaca 
$\left\{\bar{c}_{\mathrm{pw}(\mathrm{DIP})}\right\}_{\mathrm{kJ} / \mathrm{kg} \cdot{ }^{\circ} \mathrm{C}}=\left(1-\frac{100}{100+\{u\}_{\%}}+\frac{26.6}{100+\{u\}_{\%}}+\frac{0.116}{100+\{u\}_{\%}} \cdot \frac{\left\{t_{1}\right\}_{{ }^{\circ} \mathrm{C}}+\left\{t_{0}\right\}_{{ }^{\circ} \mathrm{C}}}{2}\right) \cdot 4.186$

where:

$\bar{c}_{\text {pw(WH) }}-$ mean specific heat capacity of wood (Wood Handbook),

$\bar{c}_{\mathrm{pw}(\mathrm{DEL})}$ - mean specific heat capacity of wood (Deliiski),

$\bar{c}_{\mathrm{pw}(\mathrm{DIP})}-$ mean specific heat capacity of wood (DIP),

$u$ - moisture content,

$T$ - temperature,

$t$ - temperature.

\section{CONCLUSION}

\section{ZAKLJUČAK}

The present analysis leads to the conclusion that the differences in the results obtained by different authors are significant. Most of the authors conclude that specific heat capacity depends on the temperature and wood moisture content, while variations between different wood species are very small. Regarding the discrepancy in the results obtained from different sources, future research should determine the specific heat capacity of several different species of wood, in the same temperature range and the same range of moisture content. The measurements should be made by standardized methods for measuring specific heat capacity, in order to obtain reliable results with the lowest possible measurement uncertainty. Thus obtained data for specific heat capacity can be used for testing the validity of the models suggested so far, as well as their validity and efficiency for industrial purposes.

\section{REFERENCES}

\section{LITERATURA}

1. Brown, H. P.; Panshin, A. J.; Forsaith, C. C., 1952: Textbook of Wood Technology. McGraw-Hill, New York.

2. Chudinov, B. S., 1968: Theory of Thermal Treatment of Wood. Publishing Company Nauka, Moscow, USSR.

3. Chudinov, B. S.; V. I. Stepanov, 1971: Experimental investigations for determination of the thermal properties of wood and wood-based materials. Holztechnologie, Germani. 12(3):154-159.

4. Deliiski, N., 2012: Transient Heat Conduction in Capillary Porous Bodies, University of Forestry, Bulgaria http://dx.doi.org/10.5772/21424.

5. Dunlop, F., 1912: The specific heat of wood. U.S. Dep. Agr., Forest Serv. Bull. 110.

6. Emchenko, M. P., 1958: The specific heat of wood. Derev. Prom. 7(5): 18-19.

7. Hearmon, R. F. S.; Burcham, J. N., 1955: Specific heat and heat of wetting of wood. Nature 176(4490): 978 http://dx.doi.org/10.1038/176978a0.
8. Horvat, I., Krpan, J., 1967: Drvnoindustrijski priručnik (DIP). Tehnička knjiga Zagreb.

9. Kanter, K. R., 1957: The thermal properties of wood. Nauka i Tekhnika 6(7):17-18. U.S. Dep. Com., Office Tech. Serv. OTS 60-51033.

10. Koch, P., 1969: Specific Heat of Ovendry Spruce Pine Wood and Bark. Wood Science, 1(4): 203-214.

11. Komissarov, A. P., 1969: Thermal coefficients of larch wood. Derev. Prom. 18(6):9-10. Russia.

12. Kubler, H.; Liang, L.; Chang, L. S., 1973: Thermal expansion of moist wood. Wood and Fiber. 5 (3): 257-267.

13. Kühlman, G., 1962: Investigation of the thermal properties of wood and particleboard in dependency from moisture content and temperature in the hygro-scopic range. Holz als Roh-und Werkstoff, 20(7): 259-270.

14. McMillin, C. W., 1969: Specific heat of ovendry loblolly pine wood. Wood Science 2(2): 107-111.

15. Narayanamurti, D.; Jain, N. C., 1958: A note on the specific heat of wood. Curr. Sci. 27(3): 97.

16. Tiemann, H. D., 1951: Wood Technology, Constitution, Properties, and Uses. Pitman, N.Y.

17. Twardowski, K.; Rychinski, S.; Traple, J., 2006: A Role of Water in the Porosity of Groundrock Media. Acta Montanistica Slovaca, Faculty of Drilling, Oil and Gas AGHUST, Krakow, 11(1): 208-212.

18. Wilkes, G. B.; Wood, C. O., 1942: The specific heat of thermal insulating materials. Heat. Pip. Air Cond. 14: 370-374.

19. Volbehr, B., 1896: Swelling of wood fiber. Doctoral thesis. Univ. of Kiel, Kiel, Germani.

20. ***1977: Thermal conductive properties of wood, green or dry, from $-40{ }^{\circ} \mathrm{C}$ to $+100{ }^{\circ} \mathrm{C}$ : a literature review. USDA forest service general technical report FPL9, Madison, WI: U.S. Department of Agriculture, Forest Service, Forest Products Laboratory.

21. ***1999: Wood handbook - Wood as an engineering material. General Technical Report FPL-GTR-190. Madison, WI: U.S. Department of Agriculture, Forest Service, Forest Products Laboratory. $508 \mathrm{p}$.

\section{Corresponding address:}

Assistant KRISTIJAN RADMANOVIĆ, prof. of physics and polytechnics

Department of Process Engineering,

Faculty of Forestry

University of Zagreb

Svetošimunska 25, p.p. 422

HR-10002 Zagreb, CROATIA

e-mail: kradmanovic@sumfak.hr 